Editorial

\title{
Learning, Teaching and First Aid in times of COVID-19
}

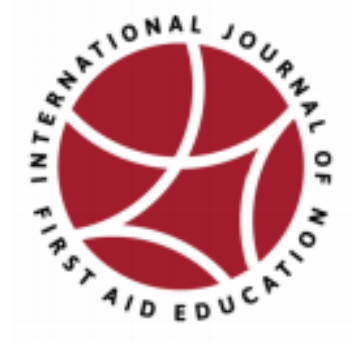

On 11 March 2020 the WHO declared the COVID-19 outbreak a pandemic, and elevated precaution measures to contain and slow down the transmission of the disease as much as possible. One important measure has been the closing down of all schools, universities and other training and education institutes and shifting to online education. The same happened to many first aid training courses, continuous first aid education and other face to face training. This has had the effect of disabling first aid educators to appropriately train millions of volunteers how to deal with COVID-19, how to keep them, their families and their communities safe, and has also limited the sharing of information on appropriate use of personal protection equipment (PPE).

Since the COVID-19 outbreak an immense level of informative and educational materials across many education topics, including first aid, has been available through digital media, academic sources and newspapers, all around the world and in different languages. Many of those sources contribute to our understanding of COVID-19, its symptoms and "possible" treatments, but also its potential impacts on the political and socioeconomic aspects of our lives. Some of them also provide evidence, perspectives and projections about the course of the disease. Whilst some stick to epidemiologic or demographic aspects of COVID-19, others shed light on societal life beyond health and discuss education, poverty, inequality, or impacts of the virus on low income households.

Disparities in opportunities for schooling and online education in particular are being touched upon in relation to the outbreak in different, examples include:

- https://en.unesco.org/themes/education-emergencies/coronavirus-school-closures

- https://www.col.org/resources/keeping-doors-learning-open-covid-19

- https://www.weforum.org/agenda/2020/03/3-ways-coronavirus-is-reshaping-education-and-whatchanges-might-be-here-to-stay/

- https://en.unesco.org/themes/education-emergencies/coronavirus-school-closures/solutions

- https://www.economist.com/international/2020/03/19/how-covid-19-is-interrupting-childrenseducation

- https://www.globalpartnership.org/gpe-and-covid-19-pandemic

- https://www.iscresearch.com/cornavirus-covid-19-update

- https://epforlearning.com/2020/ep-response-to-covid-19

- http://www.eun.org/news/detail?articleId=4938627 
- https://www.cgdev.org/blog/managing-education-systems-during-covid-19-open-letter-ministereducation

In that context, access to internet or web-enabled equipment has been referred to as a crucial factor that affects disparities in online education, which first aid education sometimes relies on. The limited reports so far indicate that disparities in access to education between the poor and the rich is increasing in the many countries around the world ("Coronavirus May Disproportionately Hurt the Poor-And That's Bad for Everyone | Time” n.d.; “The Coronavirus Exposes Education’s Digital Divide - The New York Times” n.d.). Interestingly however, the disadvantaged children in China experienced more equal access to education during the outbreak. Reportedly, the quality of the online education in private and public schools was rather more equal ("How online learning during coronavirus has changed Chinese education - SupChina" n.d.; “JRFM | Free Full-Text | Suspending Classes Without Stopping Learning: China’s Education Emergency Management Policy in the COVID-19 Outbreak | HTML” n.d.).

For those of us who are engaged in the education sector, the shift to online teaching has been challenging, requiring us to revise our approaches to training and teaching. New skills are to be learnt, new platforms are to be used, learning outcomes for courses are to be revisited, and teaching approaches are to be updated. All this had to happen in a very short period of time, and many of us shifted to online classes overnight with few (or no) previous experience. It appears that we need to dive deeper into online education and distance teaching now that the prospect of holding face to face classes is extended at least until July 2020. Many of our learners, especially those in low income countries (LIC), might have limited levels of access to fast internet (or have no internet at all), or their web-enabled devices might not be compatible with the online teaching tools of western-based online first aid courses. This raises challenges for ensuring our approach remains equitable and impartial and, importantly, supports those most in need of scalable, accurate and effective education and messaging to communities with limited healthcare provision.

Yet, hurdles in arranging first aid online training and education are beyond time zones and access to the internet. Providing equitable online education means being conscious about all forms of diversities among course participants, locals and internationals alike. For example, some participants (as well as educators) might be the only caregivers in their household and may not have flexibility in arranging their time for online education. Some may have household members who live with disabilities, cancer or rare diseases, thus increasing the stress and anxiety about the outbreak in those households. Some may be struggling with mental health issues which are linked to loneliness, isolation or quarantine, and uncertainties in this period could trigger or exacerbate their conditions. The prevalence of these conditions might well increase across more of the population due to these unprecedented circumstances. Movement restrictions or financial limitations may prevent first aiders reaching their families or people they know need care, again causing distress and exacerbating anxiety. 
Thus, shifting to online first aid education is not happening in a vacuum and is not only about changing the tools and platforms (as challenging as they might be). It is also about adapting what is already available to take account of the developing situation, alterations in population needs and adapting to first aid learning in diverse settings where many of those differences are not known or obvious to us.

Now that China's situation is improving, we could be more confident that there is light at the end of this tunnel. Thus, hope is there after all, and we need to join forces and help each other out, to pass through this period as safely and well-supported as possible. One key component in this journey would be identifying, acknowledging and accommodating diversities, whether these be cultural, contextual or personal and working to ensure that resources can support a range of different needs. It is also about creating a safe space for those who have fewer opportunities to speak up to share their needs, so they don't get left behind. It's a ripe space for 'co-production', where approaches are developed with those who need and will use them, to ensure they are appropriate and relevant.

Over the last eight years or so, we have seen the emergence of a wave of first aid apps and online courses. There is also a plethora of evidence that salutes online learning, heralding it as paving the way for access to education on a scale that has never been seen before. It also raises new questions for us to explore:

- How can we use digital learning to respond rapidly to changing health needs (such as in the time of an epidemic)?

- What disparities might this approach enhance, or reduce?

- How can we encourage self-learning in times when face-to-face learning is not possible - what can make first aid learning more appealing in these times?

- What are the longer-term implications for first aid education - will COVID-19 change the way we learn and educate beyond this current time of crisis?

\author{
Dr Thomas Wilp \\ Head of Pre-hospital Emergency Care and First Aid \\ International Committee of the Red Cross
}




\section{References}

Coronavirus May Disproportionately Hurt the Poor-And That's Bad for Everyone | Time. (n.d.). https://time.com/5800930/how-coronavirus-will-hurt-the-poor/. Accessed 1 April 2020

How online learning during coronavirus has changed Chinese education - SupChina. (n.d.). https://supchina.com/2020/02/20/china-online-learning-during-coronavirus-has-changed-statusquo/. Accessed 1 April 2020

JRFM | Free Full-Text | Suspending Classes Without Stopping Learning: China's Education Emergency Management Policy in the COVID-19 Outbreak | HTML. (n.d.). https://www.mdpi.com/19118074/13/3/55/htm. Accessed 1 April 2020

The Coronavirus Exposes Education's Digital Divide - The New York Times. (n.d.). https://www.nytimes.com/2020/03/17/technology/china-schools-coronavirus.html. Accessed 1 April 2020 